Article

\title{
Prebiotic RNA Synthesis by Montmorillonite Catalysis
}

\author{
Sohan Jheeta ${ }^{1}$ and Prakash C. Joshi ${ }^{2, *}$
}

1 NoR HGT\&LUCA, 1 Scott Hall Crescent, Leeds LS7 3RB, UK; E-Mail: sohan7@ntlworld.com

2 New York Center for Astrobiology and Department of Chemistry and Chemical Biology, Rensselaer Polytechnic Institute, Troy, NY 12180, USA

* Author to whom correspondence should be addressed; E-Mail: joship2@rpi.edu; Tel.: +1-518-276-8450.

Received: 24 December 2013; in revised form: 29 June 2014 / Accepted: 4 July 2014 / Published: 5 August 2014

\begin{abstract}
This review summarizes our recent findings on the role of mineral salts in prebiotic RNA synthesis, which is catalyzed by montmorillonite clay minerals. The clay minerals not only catalyze the synthesis of RNA but also facilitate homochiral selection. Preliminary data of these findings have been presented at the "Horizontal Gene Transfer and the Last Universal Common Ancestor (LUCA)" conference at the Open University, Milton Keynes, UK, 5-6 September 2013. The objective of this meeting was to recognize the significance of RNA in LUCA. We believe that the prebiotic RNA synthesis from its monomers must have been a simple process. As a first step, it may have required activation of the 5'-end of the mononucleotide with a leaving group, e.g., imidazole in our model reaction (Figure 1). Wide ranges of activating groups are produced from HCN under plausible prebiotic Earth conditions. The final step is clay mineral catalysis in the presence of mineral salts to facilitate selective production of functional RNA. Both the clay minerals and mineral salts would have been abundant on early Earth. We have demonstrated that while montmorillonite $(\mathrm{pH} 7)$ produced only dimers from its monomers in water, addition of sodium chloride $(1 \mathrm{M})$ enhanced the chain length multifold, as detected by HPLC. The effect of monovalent cations on RNA synthesis was of the following order: $\mathrm{Li}^{+}>\mathrm{Na}^{+}>\mathrm{K}^{+}$. A similar effect was observed with the anions, enhancing catalysis in the following order: $\mathrm{Cl}^{-}>\mathrm{Br}^{-}>\mathrm{I}^{-}$. The montmorillonite-catalyzed RNA synthesis was not affected by hydrophobic or hydrophilic interactions. We thus show that prebiotic synthesis of RNA from its monomers was a simple process requiring only clay minerals and a small amount of salt.
\end{abstract}


Keywords: catalysis; chirality; mineral salt effect; montmorillonite; prebiotic chemistry; RNA

\section{Introduction}

RNA is proposed as an important biopolymer in early life on the Earth where it would have provided both catalysis and acted as a repository of genetic information [1-4]. The "RNA World" hypothesis for the origin of life proposes that RNA formed first and that the DNA-protein world evolved from it [4-7]. Most hypotheses of the origins of biological organization suggest that RNA with chain lengths in the range of 30-50 nucleotides is needed to initiate catalysis that makes a genetic system viable [8,9]. Recent studies by Kazakoy and Altman [10], and Turk et al. [11] have demonstrated that even small oligonucleotide chains can perform catalytic activity. Ferris and coworkers $[12,13]$ have shown that the oligomerization of activated mononucleotides can be achieved by the use of a montmorillonite catalyst, which occurs naturally on Earth. The mononucleotides, formed by prebiotic processes on the primitive Earth, are likely to be present in racemic mixtures even though only D-ribose is present in naturally occurring RNA. The question is: how was chiral selection introduced into the prebiological system? We will present the results of the analysis of the products formed in the reactions of D,L-ImpA and D,L-ImpU on $\mathrm{Na}^{+}$-montmorillonite [14-18].

It is noted that a partial incorporation of sodium ions in the bilayer of montmorillonite is essential to the catalytic activity of clay minerals in our model system for RNA synthesis using phosphorimidazolides of the nucleosides [19]. The level of sodium chloride in the ancient surface ocean was 1.5-2.0 times higher than the present day level of $0.6 \mathrm{M}$, suggesting sufficient abundance of sodium ions [20-22]. Catalytic montmorillonites are also known to expand the layer spacing upon contact with water [23], indicating that the presence of hydrophilic and hydrophobic minerals may have an effect on the catalytic action of montmorillonite. Therefore, inorganic salts which tend to salt-out organic compounds from water (hydrophobic interactions) and salts, which show salt-in effects (hydrophilic interactions) were investigated to examine their role in the oligomerization process [24,25]. This review provides a comprehensive summary of one of the authors (PCJ) presentation on the significance of montmorillonite clay and mineral salts in prebiotic RNA synthesis at the "Horizontal Gene Transfer and the Last Universal Common Ancestor Conference" in the Open University, Milton Keynes, UK.

\section{Experimental Section}

\subsection{General}

Adenine, adenosine, D-5'-adenosine monophosphate (D-AMP), anhydrous sodium perchlorate $\left(\mathrm{NaClO}_{4}\right)$, cesium chloride $(\mathrm{CsCl}), 2,2^{\prime}$-dithiodipyridine, guanidine, imidazole, lithium bromide ( $\left.\mathrm{LiBr}\right)$, lithium chloride $(\mathrm{LiCl})$, lithium hydroxide $(\mathrm{LiOH})$, lithium iodide $(\mathrm{LiI})$, lithium perchlorate $\left(\mathrm{LiClO}_{4}\right)$, potassium chloride $(\mathrm{KCl})$, potassium iodide $(\mathrm{KI})$, potassium perchlorate $\left(\mathrm{KClO}_{4}\right)$, sodium bromide $(\mathrm{NaBr})$, sodium iodide $(\mathrm{NaI})$, sodium perchlorate $\left(\mathrm{NaClO}_{4}\right)$, sodium sulfate $\left(\mathrm{Na}_{2} \mathrm{SO}_{4}\right)$, triphenylphosphine, triethylamine (TEA), Trizma base (Tris) and D-5'-uridine monophosphate (D-UMP) were obtained 
from Sigma (St. Louis, MO, USA). L-adenosione-5'-monophosphate (L-AMP) and L-Uridine-5'-monophosphate (L-UMP) were obtained from ChemGenes Corp (Wilmington, MA, USA). Perchloric acid was purchased from Aldrich (St. Louis, MO, USA). Acetone, acetonitrile $\left(\mathrm{CH}_{3} \mathrm{CN}\right)$, N,N-Dimethyl-formamide (DMF), dimethyl sulfoxide (DMSO), ether, hydrochloric acid $(\mathrm{HCl})$, potassium hydroxide $(\mathrm{KOH})$ and sodium hydroxide $(\mathrm{NaOH})$ were obtained from Mallinckrodt (Phillipsburg, NJ, USA). Ultrapure molecular biology grade water was obtained from USB Corp (Cleveland, OH, USA). Anion $(\mathrm{NaCl})$ and magnesium chloride $\left(\mathrm{MgCl}_{2}\right)$ were procured from J.T. Baker (Phillipsburg, NJ, USA), Montmorillonite (Volclay ${ }^{\circledR}$ SPV-200) was a gift from the American Colloid Co. (Arlington Heights, IL, USA).

\subsection{Analytical Methods}

High-pressure liquid chromatography (HPLC) was performed on a Hitachi L-6200A intelligent pump system equipped with a Hitachi L-4000 UV detector operating at $260 \mathrm{~nm}$. The negatively charged products were separated on a Dionex DNAPac ${ }^{\circledR}-100(4.0 \times 250 \mathrm{~mm})$ analytical anion exchange column from Dionex Corporation (Sunnyvale, CA, USA) using a gradient of 0-0.4 M $\mathrm{NaClO}_{4}$ with $2 \mathrm{mM}$ Tris at $\mathrm{pH}$ 8. The HPLC analysis of the combined extract of the reaction mixture to determine the length of oligomer was carried out on an ion exchange column using a gradient of 0-0.4 $\mathrm{M} \mathrm{NaClO}_{4}$ with $2 \mathrm{mM}$ Tris at $\mathrm{pH} 8$ (Scheme 1). For the collection of a sufficient quantity of both dimer and oligomers, the separation of the oligomer mixture was carried out using a modified elution system consisting of a gradient of $2 \mathrm{mM}-2 \mathrm{M}$ ammonium acetate on the same ion exchange column. The separation profile of the oligomers with this reagent was not as good as observed with the $\mathrm{NaClO}_{4}$ and Tris reagent, but the presence of a huge amount of sodium perchlorate in the sample was avoided. The oligomers were collected by multiple injections. The sample was freeze dried, re-dissolved in $1 \mathrm{~mL} \mathrm{H}_{2} \mathrm{O}$ and, if necessary, purified further by HPLC using same elution reagent. The re-purified and 5'-end dephosphorylated products were analyzed on a C-18 reverse phase column where they were resolved into multiple peaks.

\subsection{Preparation of Catalytic Montmorillonite}

Volclay $^{\circledR}(12 \mathrm{~g})$ was treated with $0.5 \mathrm{M} \mathrm{HCl}(50 \mathrm{~mL})$ by continuous stirring at $4{ }^{\circ} \mathrm{C}$ for $30 \mathrm{~min}$. At the end of each treatment, excess acid was removed by centrifugation $(3500 \mathrm{rpm})$ and decanting the supernatant. Fresh acid $(50 \mathrm{~mL})$ was added to the montmorillonite pellet and the treatment was repeated twice more. $\mathrm{H}^{+}$-montmorillonite was washed with $100 \mathrm{~mL}$ deionized water at $4{ }^{\circ} \mathrm{C}$ for $30 \mathrm{~min}$ with constant stirring. At the end of the washing, excess water was separated by centrifugation ( $3500 \mathrm{rpm})$ and decanting of the supernatant. Washing with water $(100 \mathrm{~mL})$ was repeated three times. The $\mathrm{H}^{+}$-montmorillonite slurry was added to water $(1000 \mathrm{~mL})$ and to this was added $45 \mathrm{~mL}$ of wet anion exchange resin to remove the residual $\mathrm{HCl}$. The mixture was stirred for $30 \mathrm{~min}, \mathrm{pH}$ was measured $(3.00 \pm 0.2)$, the anion exchange resin was removed by filtration using a stainless steel sieve (115 mesh) and the $\mathrm{H}^{+}$-montmorillonite slurry was removed and freeze dried. One gram of $\mathrm{H}^{+}$-montmorillonite was suspended in $100 \mathrm{~mL}$ of deionized water and was titrated with $0.02 \mathrm{M}$ aqueous $\mathrm{NaOH}, \mathrm{LiOH}$ or $\mathrm{KOH}$ to $\mathrm{pH}$ 7. The water was separated by centrifugation $(3500 \mathrm{rpm})$ and the $\mathrm{Li}^{+}, \mathrm{Na}^{+}$and $\mathrm{K}^{+}$-montmorillonite pellets were freeze dried. 


\subsection{Preparation of the Activated Nucleotide of AMP}

A mixture of 5'-mononucleotide (AMP, free acid, $0.16 \mathrm{mmol}$, Figure 1) and imidazole (2.2 mmol) was dissolved in DMF $(5 \mathrm{~mL})$ in a $50 \mathrm{~mL}$ flask and the solvent was evaporated to near dryness at a reduced pressure. The evaporation was repeated twice with DMF $(2 \times 5 \mathrm{~mL})$ to remove residual water. The residue was dissolved in DMF $(2 \mathrm{~mL})$ and DMSO $(2 \mathrm{~mL})$ and stirred with 2,2'-dithiodipyridine $(0.64 \mathrm{mmol})$, triphenyl phosphine $(0.46 \mathrm{mmol})$ and TEA $(0.65 \mathrm{mmol})$ for $3 \mathrm{~h}$. The resulting product was recovered from the clear yellow reaction mixture as a precipitate by adding the reaction mixture drop by drop to a solution of $\mathrm{NaClO}_{4}(0.35 \mathrm{~g})$ in a mixture of ether $(30 \mathrm{~mL})$, acetone $(20 \mathrm{~mL})$ and TEA $(2 \mathrm{~mL})$, stirring at the same time. The stirring was continued for $2 \mathrm{~h}$ (to ensure complete formation of $\mathrm{Na}^{+}$salt) and a colorless, flocculent solid was precipitated which was allowed to settle (15 min). The supernatant was decanted and the remaining reaction mixture was centrifuged. The resulting colorless pellet was washed twice with a mixture of ether $(50 \mathrm{~mL})$ and acetone $(50 \mathrm{~mL})$ and then with ether $(2 \times 50 \mathrm{~mL})$ and dried overnight in a vacuum desiccator. Their purities were determined by reverse phase HPLC (purity $>99.9 \%$ ).

Figure 1. Structures of 5'-adenosine-monophosphate (AMP), 5'-phosphorimidazolide of adenosine (ImpA), linear and cyclic dimers.

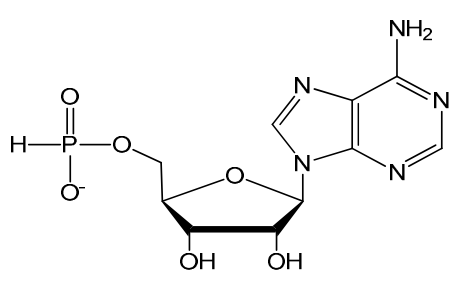

AMP

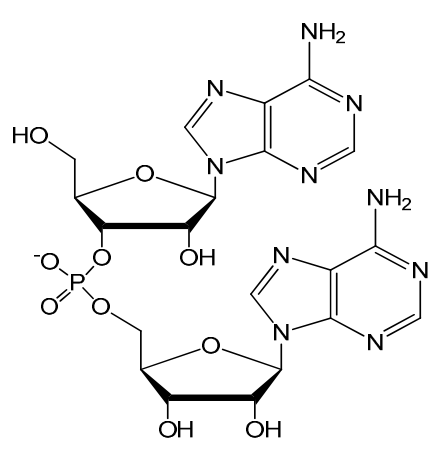

Linear Dimer
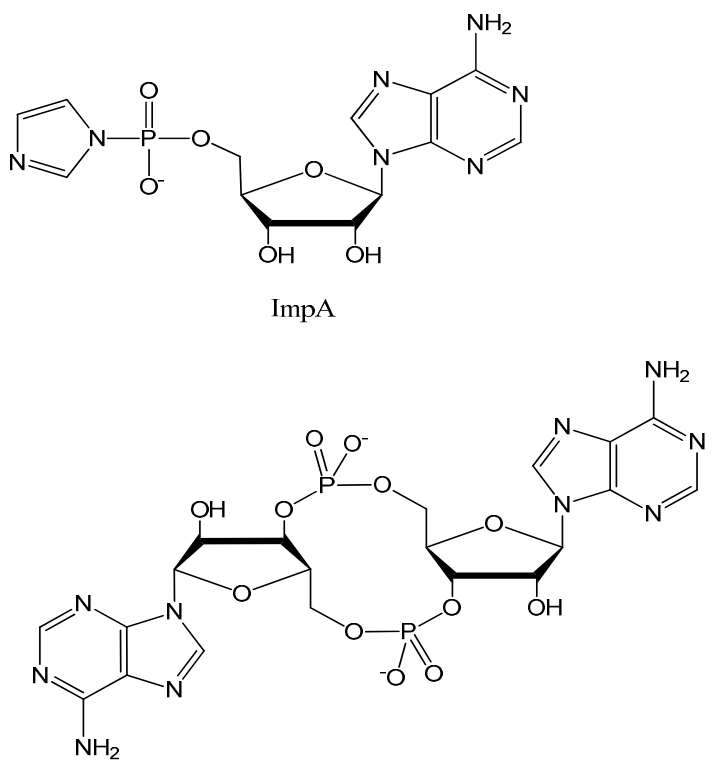

Cyclic Dimer

\subsection{Montmorillonite-Catalyzed Oligomerization of $\operatorname{ImpA}$}

Three sets of reactions were carried out:

Reaction 1. D-ImpA (15 mM, Figure 1) on $\mathrm{Na}^{+}$-montmorillonite both with and without salts;

Reaction 2. D-ImpA with D-ImpU (Total $15 \mathrm{mM}$ ) on $\mathrm{Na}^{+}$-montmorillonite; and

Reaction 3. D,L-ImpA with D,L-ImpU (Total $15 \mathrm{mM}$ ) on $\mathrm{Na}^{+}$-montmorillonite.

The stock solution of activated nucleotide $(15 \mathrm{mM})$ was prepared either in $\mathrm{H}_{2} \mathrm{O}, 1 \mathrm{M} \mathrm{NaCl}$, a mixture of $\mathrm{NaCl}(0.2 \mathrm{M})$ and $\mathrm{MgCl}_{2}(0.075 \mathrm{M})$ or other inorganic salts, usually $1 \mathrm{M}$ unless stated. 
For Reaction 1, 200- $\mu \mathrm{L}$ reaction mixture was added to $10 \mathrm{mg} \mathrm{Na}^{+}$-montmorillonite, the suspension was vortexed and allowed to stand at $24{ }^{\circ} \mathrm{C}$ for a period of $72 \mathrm{~h}$ (Scheme 1). For Reactions 2 and 3, stock solutions of D-ImpA, L-ImpA, D-ImpU and L-ImpU (15 mM each) were prepared in a $0.075 \mathrm{M}$ magnesium chloride and $0.2 \mathrm{M}$ sodium chloride reagent. The ImpA and ImpU concentrations were determined by quantitative HPLC analysis of $10^{-5} \mathrm{M}$ samples on a reverse phase column. The D- and L- mixtures of activated nucleotides were prepared at a total concentration of $15 \mathrm{mM}$ in $0.075 \mathrm{M}$ magnesium chloride and $0.2 \mathrm{M}$ sodium chloride reagent by mixing the correct volume of each solution calculated on the basis of HPLC analyses. For Reaction 2, $200 \mu \mathrm{L}$ of D-ImpA with equimolar D-ImpU were reacted with $10 \mathrm{mg} \mathrm{Na}^{+}$-montmorillonite. The total concentration of activated mononucleotides was $15 \mathrm{mM}$. For Reaction 3, $200 \mu \mathrm{L}$ of a racemic mixture of D,L-ImpA with equimolar D,L-ImpU were reacted with $10 \mathrm{mg} \mathrm{Na}{ }^{+}$-montmorillonite. The total concentration of activated mononucleotides was $15 \mathrm{mM}$. The reaction mixtures were vortexed and allowed to stand at $25^{\circ} \mathrm{C}$ for 3 days (Scheme 1). The supernatant was collected from reaction mixtures containing $\mathrm{Na}^{+}$-montmorillonite by centrifugation at $14,000 \mathrm{rpm}$ for $8 \mathrm{~min}$. Further reaction products were desorbed from $\mathrm{Na}^{+}$-montmorillonite by extracting four times $(2 \times 1 \mathrm{~h}$, overnight and $1 \times 1 \mathrm{~h})$ with $200 \mu \mathrm{L}$ each of $30 \% \mathrm{CH}_{3} \mathrm{CN}$ in $0.1 \mathrm{M} \mathrm{NaCl}$ elution reagent. The extracts were collected by centrifugation and combined with the supernatant to give $0.9 \mathrm{~mL}$ of combined extracts. The combined extracts were diluted to $1.0 \mathrm{~mL}$ and filtered (Alltima $0.45 \mu \mathrm{m}$ nylon syringe filter), adjusted to $\mathrm{pH} 4$ with $1 \mathrm{M}$ perchloric acid and incubated at $37^{\circ} \mathrm{C}$ for $4 \mathrm{~h}$ to cleave any unreacted imidazole groups from the activated nucleotides. The samples were analyzed by HPLC using an ion exchange column. The individual products (dimer, trimer, tetramer and pentamer fractions) were separated from the combined extracts on an ion exchange column and analyzed further on a reverse phase column.

Scheme 1. Model reaction of the phosphorimidazolide of adenosine on $\mathrm{Na}^{+}$-montmorillonite.

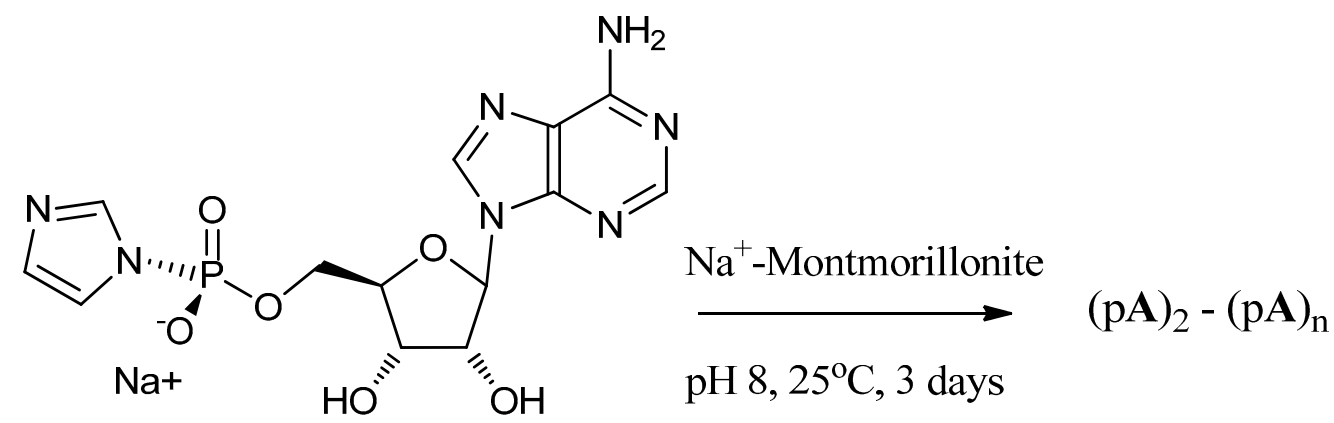

\subsection{Reaction and Analysis in the Absence of Minerals}

Control solutions of Reaction 1 were prepared in an appropriate salt $(200 \mu \mathrm{L})$ without $\mathrm{Na}^{+}$-montmorillonite. For control Reactions 2 and 3, samples were prepared in a $0.075 \mathrm{M}$ magnesium chloride and $0.2 \mathrm{M}$ sodium chloride reagent $(200 \mu \mathrm{L})$ without $\mathrm{Na}^{+}$-montmorillonite. The total concentration of activated mononucleotides was $15 \mathrm{mM}$. The mixtures were allowed to stand at $25{ }^{\circ} \mathrm{C}$ for 3 days. At the end of the reaction time, the mixture was diluted to $1.0 \mathrm{~mL}$ with the $30 \% \mathrm{CH}_{3} \mathrm{CN}$ in $0.1 \mathrm{M} \mathrm{NaCl}$ reagent, adjusted to $\mathrm{pH} 4$ with $1 \mathrm{M} \mathrm{HClO}_{4}$ and incubated at $37{ }^{\circ} \mathrm{C}$ for $4 \mathrm{~h}$ to cleave any unreacted imidazole group from the activated nucleotides. The sample was analyzed on a Dionex ion exchange HPLC column. 


\subsection{Enzymatic Hydrolysis of Reaction Products}

Dephosphorylation of the oligomer fractions to cleave the 5'-terminal phosphate group was carried out by treating the samples $(500 \mu \mathrm{L})$ with $\mathrm{APH}(0.5$ units $)$ at $\mathrm{pH} 8$ and incubation at $37{ }^{\circ} \mathrm{C}$ for $1 \mathrm{~h}$, prior to their analysis on a reverse phase HPLC column.

\section{Results and Discussion}

\subsection{Significance of the Investigation}

This investigation was carried out to examine whether the $\mathrm{Na}^{+}$-montmorillonite-catalyzed reactions of activated mononucleotides are able to generate RNA oligomers and also if the same system may facilitate chiral selection in a racemic mixture. This is an important consideration because if activated mononucleotides were formed by prebiotic processes, it is likely that both enantiomers were present on the primitive Earth as a racemic mixture [26,27]. This study on the role of montmorillonite clay mineral catalysis in the formation of RNA oligomers on the primitive Earth provides insight into the selectivity of this potential prebiotic catalyst.

\subsection{Oligomerization of Activated Mononucleotide on $\mathrm{Na}^{+}$-Montmorillonite}

The oligomerization reaction of $15 \mathrm{mM}$ activated D-mononucleotide on $\mathrm{Na}^{+}$-montmorillonite produced oligomers as long as 9-mers as determined by HPLC analysis on an ion exchange column (Scheme 1). The chain length of oligomers increased to 11-mer in racemic (D, L) reaction (Scheme 2), also see Figure 3. It has been established earlier that the increase in chain length of oligomers in a racemic reactions is largely due to the reduction in the yield of cyclic dimers [18]. Oligomerization reactions in the absence of $\mathrm{Na}^{+}$-montmorillonite resulted in the formation of no products beyond cyclic dimers and traces of linear dimers. The activated mononucleotides were hydrolyzed to their respective mononucleotides in $>99 \%$ yield in the absence of $\mathrm{Na}^{+}$-montmorillonite. When the oligomerization of ImpA with $\mathrm{Na}^{+}$-montmorillonite was carried out in water, the cyclic dimers were the major reaction products $(63.7 \%)$, with the linear dimers at $1.8 \%$ and traces of trimer were also detected (Table 1). The results showed that $\mathrm{Na}^{+}$-montmorillonite by itself is a poor catalyst. Earlier work has shown that highly acidic montmorillonite produced only pyrophosphates and AMP, whereas, alkaline montmorillonite produced mainly AMP. The longer oligomeric products were formed within a narrow window between pH 6-8 [28].

Table 1. A comparison of the homochirality between observed versus calculated values in a reaction mixture of D,L-ImpA with D,L-ImpU on $\mathrm{Na}^{+}$-montmorillonite.

\begin{tabular}{cccccc}
\hline Homochirality & Monomer & Dimer & Trimer & Tetramer & Pentamer \\
\hline Observed & $50 \%$ & $63.5 \%$ & $74.3 \%$ & $92.7 \%$ & $97.2 \%$ \\
Calculated & $50 \%$ & $50 \%$ & $25 \%$ & $12.5 \%$ & $6.25 \%$ \\
\hline
\end{tabular}


Scheme 2. Reaction of the racemic phosphorimidazolides of adenosine and uridine on $\mathrm{Na}^{+}$-montmorillonite.
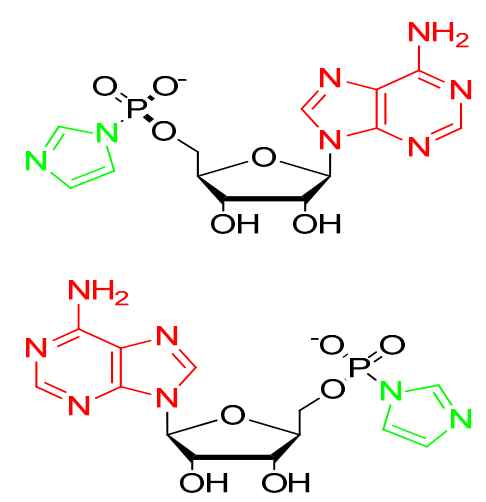
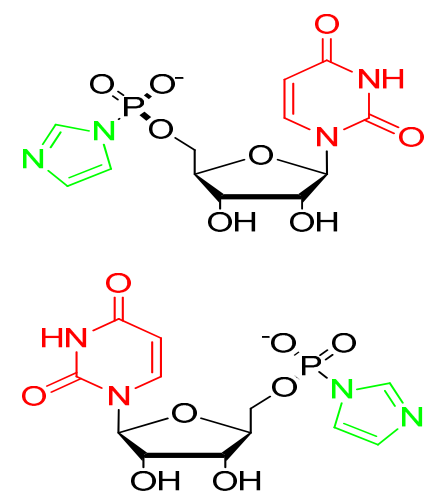

\section{Montmorillonite}

$\mathrm{pH} 7,25^{\circ} \mathrm{C}, 3$ days
$(\mathrm{pN})_{2}$ to $(\mathrm{pN})_{11}$

(as determined by HPLC where $\mathrm{N}=\mathrm{D} / \mathrm{L}-\mathrm{A}, \mathrm{D} / \mathrm{L}-\mathrm{U}$ )

\subsection{Analysis of the Products of Reaction}

The identification and characterization of dimers and higher oligomers was based on the analysis of oligomers isolated from the reaction mixture of $15 \mathrm{mM}$ activated mononucleotides on $\mathrm{Na}^{+}$-montmorillonite. This reaction produced oligomers up to 11-mers as detected by HPLC. However, for an accurate assessment of homochirality of dimers, an ideal condition was considered to be where no trimers are detected. Likewise, for the determination of the homochirality of trimers, an ideal condition will be where no tetramers are detected. Therefore, the $\mathrm{Na}^{+}$-montmorillonite catalyzed reactions of D,L-ImpA with D,L-ImpU were also carried out at a very low $(0.15-4.8 \mathrm{mM})$ total concentration of the activated mononucleotides. All the dimers that were identified from a $15 \mathrm{mM}$ reaction of activated mononucleotides were also detected at $0.15 \mathrm{mM}$ concentrations and they followed a similar HPLC elution profile, as was observed with the dimers isolated from $15 \mathrm{mM}$ reactions. Similarly, the trimers that were identified from the $15 \mathrm{mM}$ reaction mixture were also detected at $1.5 \mathrm{mM}$ concentration and they also followed a similar HPLC elution profile on a C-18 column. This result suggested that the relative ratios of dimers and trimers are independent of the initial concentration of the reactants. Reaction 2 produced oligomers as long as 9-mers as determined by HPLC analysis on an ion exchange column. The chain length of oligomers increased to 11-mers in Reaction 3 (Scheme 2 and Figure 2). The dimer fraction of Reaction 3 after APH hydrolysis resulted in the detection of 18 peaks on the Alltima C-18 column. The major peaks were identified as uridine and adenosine. Of the remaining 15 peaks, 12 linear and three cyclic dimers were isolated and characterized. The homochirality of dimers was $63.5 \%$. Out of the 16 trimers isolated, 10 were homochiral with an overall homochirality of $74.2 \%$. The tetramers and pentamers were separated into 24 and 20 isomers, respectively. Their co-elution with those formed in Reaction 2 revealed $92.7 \%$ and $97.2 \%$ homochirality, respectively (Table 1). 
Figure 2. Anion exchange HPLC analysis of the $\mathrm{Na}^{+}$-montmorillonite catalyzed reaction of $15 \mathrm{mM}$ D, L-ImpA with D, L-ImpU. Oligomer length up to 11-mer was detected. Cyclic (2C) and linear (2 L) dimers are eluted separately.

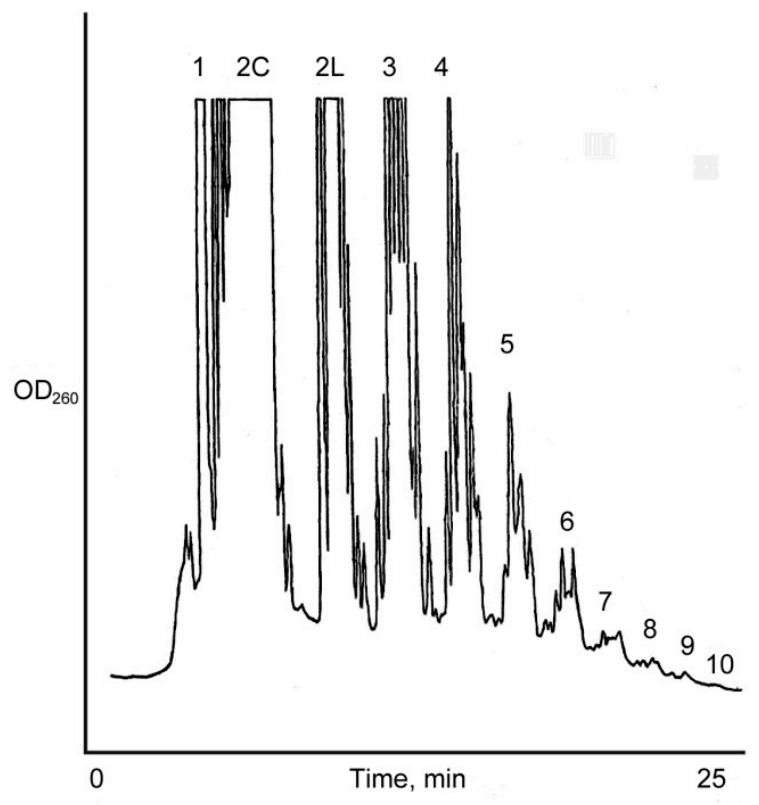

\subsection{Effect of Salts in the Oligomerization of ImpA with $\mathrm{Na}^{+}$-Montmorillonite}

This study was designed to investigate the possible role of inorganic salts in montmorillonite-catalyzed RNA synthesis. Particular emphasis was given to sodium chloride as its level in the ancient surface ocean was about $0.9-1.2 \mathrm{M}$, which is 1.5-2.0 times the present level of 0.6 M [20-22]. In our model prebiotic RNA synthesis system, the oligomerization of activated mononucleotides takes place within the clay layers in the presence of sodium chloride without any involvement of protecting groups. According to our findings, monovalent cations are essential in the model reactions [29]. $\mathrm{Na}^{+}$-montmorillonite alone did not produce products beyond dimer. However, addition of sodium chloride $(0.1-2.0 \mathrm{M})$ to the ImpA and $\mathrm{Na}^{+}$-montmorillonite mixture increased oligomer length by at least a factor of 5-10, as determined by HPLC. Interestingly, the optimum oligomer chain length was detected at $1 \mathrm{M}$ sodium chloride, which coincided with its abundance in the ancient oceans (0.9-1.2 M). Higher salinity reduced the formation of cyclic dimers, which are known to be a contributing factor in limiting the formation of preferred linear RNA. Magnesium chloride $(0.075 \mathrm{M})$ produced oligomers up to 10-mers compared with small amount of dimers and traces of trimer formed without it. Sodium chloride $(0.075 \mathrm{M})$ alone produced oligomers up to 6-mer under similar conditions. Magnesium chloride $(0.075 \mathrm{M})$ and sodium chloride $(1 \mathrm{M})$ together produced nearly the same outcome as those from sodium chloride $(1 \mathrm{M})$ alone. The concentration of $\mathrm{Mg}^{2+}$ as combined $\mathrm{MgCl}_{2}$ and $\mathrm{MgSO}_{4}$ in the ocean today is approximately $0.05 \mathrm{M}$, which is about $8.3 \%$ of the current level of sodium chloride [30]. A similar ratio of these salts is likely to have been maintained in the ancient ocean. In this study, we have shown that although magnesium chloride enhanced the catalysis by $\mathrm{Na}^{+}$-montmorillonite, there was a similar effect when $\mathrm{Na}^{+}$replaced the $\mathrm{Mg}^{2+}$. Therefore, $\mathrm{Mg}^{2+}$ is unnecessary, in contrast to what was previously thought. Therefore our model reaction system is now even more attractive, since it is even simpler. We now propose that saline clay mineral alone was needed to catalyze prebiotic RNA 
synthesis. A $1 \mathrm{M}$ sodium chloride provided optimum oligomer length and product yield. The results from varying concentrations of sodium chloride are shown in Table 2. The yields of cyclic dimers (Figure 1) decreased from $76.9 \%-33.7 \%$ upon increasing the concentration of sodium chloride from $0.1 \mathrm{M}-2 \mathrm{M}$. However, the hydrolysis of ImpA to AMP also increased from $12.9 \%-51.6 \%$ under similar conditions.

Table 2. Reaction of ImpA (15 mM) with $\mathrm{Na}^{+}$-montmorillonite $(10 \mathrm{mg} / 200 \mu \mathrm{L})$ in the presence or absence of sodium chloride and/or magnesium chloride (72 h).

\begin{tabular}{|c|c|c|c|c|c|c|c|c|c|c|c|c|c|}
\hline \multirow{2}{*}{ Reagent } & \multicolumn{13}{|c|}{ Percentage Yield of Oligomers } \\
\hline & $\mathbf{I}$ & IIc * & IIL ** & III & IV & $\mathbf{V}$ & VI & VII & VIII & IX & $\mathbf{X}$ & $\mathbf{X I}$ & XII \\
\hline \multicolumn{14}{|c|}{ Effect of sodium chloride } \\
\hline $2.0 \mathrm{M}$ & 51.6 & 33.7 & 9.32 & 3.15 & 1.40 & 0.62 & 0.12 & 0.05 & 0.03 & $\mathrm{~T}$ & & & \\
\hline $1.0 \mathrm{M}$ & 24.9 & 52.2 & 13.6 & 4.84 & 2.29 & 1.12 & 0.58 & 0.27 & 0.14 & 0.05 & 0.01 & & \\
\hline $0.2 \mathrm{M}$ & 15.8 & 68.5 & 12.0 & 2.68 & 0.79 & 0.21 & 0.02 & $\mathrm{~T}$ & & & & & \\
\hline $0.1 \mathrm{M}$ & 12.9 & 76.9 & 8.55 & 1.38 & 0.29 & 0.08 & & & & & & & \\
\hline \multicolumn{14}{|c|}{ Effect of sodium chloride (1 M) and/or magnesium chloride $(0.075 \mathrm{M})$} \\
\hline $\mathrm{NaCl}$ & 21.1 & 58.8 & 12.6 & 4.06 & 1.89 & 0.96 & 0.29 & 0.14 & 0.10 & 0.06 & $\mathrm{~T}$ & & \\
\hline $\mathrm{MgCl}_{2}$ & 22.0 & 57.4 & 12.7 & 4.70 & 1.83 & 0.80 & 0.35 & 0.13 & 0.06 & 0.03 & $\mathrm{~T}$ & & \\
\hline \multicolumn{14}{|c|}{ Effect of salt-in reagents $(1 \mathrm{M})$} \\
\hline $\mathrm{LiClO}_{4}$ & 15.3 & 60.3 & 11.4 & 5.75 & 3.13 & 1.73 & 1.20 & 0.62 & 0.33 & 0.17 & 0.05 & 0.03 & \\
\hline Guanidine & 53.2 & 26.1 & 10.5 & 4.58 & 2.39 & 1.41 & 0.81 & 0.47 & 0.26 & 0.17 & 0.05 & 0.04 & 0.02 \\
\hline \multicolumn{14}{|c|}{ Effect of salt-out reagents $(1 \mathrm{M})$} \\
\hline $\mathrm{Na}_{2} \mathrm{SO}_{4}$ & 11.4 & 60.5 & 13.0 & 6.17 & 3.36 & 1.93 & 1.40 & 0.81 & 0.52 & 0.40 & 0.32 & 0.19 & $\mathrm{~T}$ \\
\hline $\mathrm{LiCl}$ & 12.3 & 62.1 & 12.5 & 5.71 & 2.79 & 1.66 & 1.41 & 0.68 & 0.37 & 0.27 & 0.15 & 0.07 & $\mathrm{~T}$ \\
\hline \multicolumn{14}{|c|}{ Effect of reagents with no salt-in or salt-out effect $(1 \mathrm{M})$} \\
\hline $\mathrm{LiBr}$ & 12.5 & 60.3 & 11.8 & 6.15 & 3.44 & 1.97 & 1.55 & 0.92 & 0.54 & 0.39 & 0.23 & 0.13 & 0.08 \\
\hline \multicolumn{14}{|c|}{ Effect of no salts } \\
\hline $\mathrm{H}_{2} \mathrm{O}$ & 34.5 & 63.7 & 1.80 & $\mathrm{~T}$ & & & & & & & & & \\
\hline
\end{tabular}

\subsection{Effect of Hydrophilic and Hydrophobic Salts in the Oligomerization of ImpA Catalyzed by} $\mathrm{Na}^{+}$-Montmorillonite

Our previous studies with clay minerals revealed that the catalytic clays always swell in water, whereas, non-catalytic clays by and large do not have this property [19,28]. It is known that in the reactions carried out in an aqueous medium, the swelling of clay minerals is caused by the hydration of the exchangeable cations of the dry clay [23]. Therefore, $\mathrm{Na}^{+}$-montmorillonite catalyzed oligomerization reactions were carried out with mineral salts that tend to salt out organic compounds from water. Inorganic salts like sodium sulfate and lithium chloride did not show any preference for hydrophobic interactions in the $\mathrm{Na}^{+}$-montmorillonite catalyzed RNA synthesis. Similarly, salts that show salt-in effect (e.g., lithium perchlorate and guanidine) also showed no preference for hydrophilic interactions. Additionally, salts with no reported salt-in or salt-out effect such as lithium bromide did not produce any unusual outcomes (Table 2). This study clearly showed that a wide range of mineral 
salts might have contributed to the prebiotic RNA synthesis with no apparent bias for hydrophilic or hydrophobic interactions, although specific cations and anions may have had more impact than others.

\subsection{Effect of Monovalent Cations and Anions in the Oligomerization of ImpA Catalyzed by $\mathrm{Na}^{+}$-Montmorillonite}

The effect of cations upon the length of the oligomers was: $\mathrm{Li}^{+}>\mathrm{Na}^{+}>\mathrm{K}^{+}$. The yields of dimers (both linear and cyclic) as well as oligomers (III-XII, Table 3) were marginally higher with lithium chloride than with sodium chloride. Similar results were obtained with the perchlorate and iodide salts of $\mathrm{Li}^{+}, \mathrm{Na}^{+}$and $\mathrm{K}^{+}$[29]. In the reactions of ImpA with $\mathrm{Na}^{+}$-montmorillonite carried out separately in $1 \mathrm{M}$ sodium chloride, sodium bromide and sodium iodide (Table 3), oligomers up to 11-mers, 10-mers and 9-mers, respectively, were detected. Their yields were marginally higher in sodium chloride compared with sodium bromide. Sodium iodide caused $48.1 \%$ hydrolysis of ImpA to AMP as compared to sodium bromide (23.9\%) and sodium chloride $(24.9 \%)$.

Table 3. Effect of cations and anions on the oligomerization of ImpA catalyzed by $\mathrm{Na}^{+}$-montmorillonite.

\begin{tabular}{|c|c|c|c|c|c|c|c|c|c|c|c|c|c|}
\hline \multirow{2}{*}{$\begin{array}{l}\text { Oligomer } \\
\text { Length } \rightarrow\end{array}$} & \multicolumn{13}{|c|}{ Percentage Yield of Oligomers } \\
\hline & I & $\mathbf{I I}_{\mathbf{c}} *$ & $\mathbf{I I}_{\mathbf{L}} * *$ & III & IV & $\mathbf{V}$ & VI & VII & VIII & IX & $\mathbf{X}$ & $\mathbf{X I}$ & XII \\
\hline \multicolumn{14}{|c|}{ Effect of cations (1 M) with Chloride as a common ion } \\
\hline $\mathrm{LiCl}$ & 12.3 & 62.0 & 12.5 & 5.68 & 2.79 & 1.65 & 1.41 & 0.68 & 0.36 & 0.29 & 0.22 & 0.12 & $\mathrm{~T}$ \\
\hline $\mathrm{NaCl}$ & 24.9 & 52.2 & 13.6 & 4.84 & 2.29 & 1.12 & 0.58 & 0.27 & 0.14 & 0.05 & 0.01 & $\mathrm{~T}$ & \\
\hline $\mathrm{KCl}$ & 72.2 & 21.2 & 5.29 & 1.10 & 0.34 & 0.05 & 0.02 & $\mathrm{~T}$ & & & & & \\
\hline \multicolumn{14}{|c|}{ Effect of anions $(1 \mathrm{M})$ with sodium as a common ion } \\
\hline $\mathrm{NaCl}$ & 24.9 & 52.2 & 13.6 & 4.84 & 2.29 & 1.12 & 0.58 & 0.27 & 0.14 & 0.05 & 0.01 & $\mathrm{~T}$ & \\
\hline $\mathrm{NaBr}$ & 23.9 & 55.2 & 11.9 & 4.48 & 2.16 & 1.15 & 0.65 & 0.35 & 0.14 & 0.08 & $\mathrm{~T}$ & & \\
\hline $\mathrm{NaI}, 1 \mathrm{M}$ & 48.1 & 39.5 & 7.95 & 2.56 & 1.07 & 0.52 & 0.23 & 0.05 & 0.02 & $\mathrm{~T}$ & & & \\
\hline
\end{tabular}

* Cyclic dimer; $* *$ Linear dimer; $\mathrm{T}=$ trace.

\subsection{Effect of Homoionic Salts in the Oligomerization of ImpA Catalyzed by $\mathrm{Na}^{+}$-Montmorillonite}

The catalytic action of $\mathrm{Li}^{+}$-montmorillonite, $\mathrm{Na}^{+}$-montmorillonite and $\mathrm{K}^{+}$-montmorillonite with $\operatorname{ImpA}$ was investigated in aqueous solutions of $1 \mathrm{M}$ lithium chloride, sodium chloride or potassium chloride, respectively (Table 4). The longest oligomers (11-mers) were detected in the reaction of ImpA with $\mathrm{Li}^{+}$-montmorillonite in $1 \mathrm{M}$ lithium chloride. By changing the reagents in the $\mathrm{ImpA}$ and $\mathrm{Li}^{+}$-montmorillonite reaction mixture with $1 \mathrm{M}$ sodium chloride or $1 \mathrm{M}$ potassium chloride we observed reductions in chain lengths of oligomers to 10-mers and 6-mers, respectively. Likewise, in the reactions of ImpA with $\mathrm{Na}^{+}$-montmorillonite or $\mathrm{K}^{+}$-montmorillonite in $1 \mathrm{M}$ lithium chloride, oligomers up to 11-mers and 9-mers in length were detected. In general, the yield of oligomers formed in both lithium chloride and sodium chloride was comparable and the degree of hydrolysis of ImpA to AMP was in the lower range $(12 \%-25 \%)$. However, reactions carried out in potassium chloride led to considerable hydrolysis of $\operatorname{ImpA}(72 \%-73 \%)$ and oligomers only up to 6-7-mers were detected in relatively low yields. 
Table 4. A comparison of the influence of homoionic salts with homoionic montmorillonite on the oligomerization of ImpA.

\begin{tabular}{|c|c|c|c|c|c|c|c|c|c|c|c|c|}
\hline \multirow{2}{*}{$\begin{array}{c}\text { Oligo Length } \rightarrow \\
\text { Salt Concentration } \downarrow\end{array}$} & \multicolumn{12}{|c|}{ Percentage Yield of Oligomers } \\
\hline & $\mathbf{I}$ & $\mathbf{I I}_{\mathbf{c}} *$ & $\mathbf{I}_{\mathbf{L}} * *$ & III & IV & $\mathbf{V}$ & VI & VII & VIII & IX & $\mathbf{X}$ & $\mathbf{X I}$ \\
\hline \multicolumn{13}{|c|}{ Li ${ }^{+}$-Montmorillonite } \\
\hline $\mathrm{LiCl}, 1 \mathrm{M}$ & 16.0 & 60.0 & 12.6 & 5.47 & 2.74 & 1.38 & 0.97 & 0.45 & 0.23 & 0.13 & 0.03 & $\mathrm{~T}$ \\
\hline $\mathrm{NaCl}, 1 \mathrm{M}$ & 20.1 & 58.9 & 11.7 & 4.32 & 1.95 & 1.00 & 0.55 & 0.25 & 0.13 & 0.10 & $\mathrm{~T}$ & \\
\hline $\mathrm{KCl}, 1 \mathrm{M}$ & 72.6 & 21.5 & 4.73 & 0.95 & 0.17 & 0.05 & $\mathrm{~T}$ & & & & & \\
\hline \multicolumn{13}{|c|}{$\mathrm{Na}^{+}$-Montmorillonite } \\
\hline $\mathrm{LiCl}, 1 \mathrm{M}$ & 12.5 & 63.0 & 12.3 & 5.56 & 2.77 & 1.64 & 0.92 & 0.62 & 0.34 & 0.21 & 0.14 & $\mathrm{~T}$ \\
\hline $\mathrm{NaCl}, 1 \mathrm{M}$ & 24.9 & 52.2 & 13.6 & 4.84 & 2.29 & 1.12 & 0.58 & 0.27 & 0.14 & 0.05 & 0.01 & $\mathrm{~T}$ \\
\hline $\mathrm{KCl}, 1 \mathrm{M}$ & 72.0 & 21.2 & 5.29 & 1.10 & 0.35 & 0.04 & 0.02 & $\mathrm{~T}$ & & & & \\
\hline \multicolumn{13}{|c|}{$K^{+}$-Montmorillonite } \\
\hline $\mathrm{LiCl}, 1 \mathrm{M}$ & 13.2 & 63.2 & 12.2 & 5.39 & 2.54 & 1.59 & 0.97 & 0.48 & 0.25 & 0.18 & & \\
\hline $\mathrm{NaCl}, 1 \mathrm{M}$ & 21.9 & 57.9 & 11.9 & 4.36 & 2.00 & 1.06 & 0.59 & 0.29 & $\mathrm{~T}$ & & & \\
\hline $\mathrm{KCl}, 1 \mathrm{M}$ & 73.4 & 21.0 & 4.54 & 0.92 & 0.12 & 0.02 & $\mathrm{~T}$ & & & & & \\
\hline
\end{tabular}

\section{Conclusions}

Montmorillonite catalyzed RNA synthesis and facilitated homochiral selection. The reaction depended on the salinity of the reaction medium. Optimum catalytic activity of $\mathrm{Na}^{+}$-montmorillonite was observed between $0.8-1.2 \mathrm{M} \mathrm{NaCl}$, which resembles its concentration in the ancient oceans. Smaller cations $\left(\mathrm{Li}^{+}>\mathrm{Na}^{+}>\mathrm{K}^{+}\right)$and anions $\left(\mathrm{Cl}^{-}>\mathrm{Br}^{-}>\mathrm{I}^{-}\right)$showed increasing activity in producing longer oligomers.

\section{Acknowledgments}

The authors are grateful to Douglas Whittet (Director of New York Center for Astrobiology) and Curt Breneman (Chairman, Department of Chemistry \& Chemical Biology) for their support and keen interest in this research. This research was supported by NASA Astrobiology Institute grant NNA09DA80A.

\section{Author Contributions}

Prakash C. Joshi designed research, performed research and analyzed the data, Sohan Jheeta wrote the paper. All authors have read and approved the final manuscript.

\section{Conflicts of Interest}

The authors declare no conflict of interest.

\section{References}

1. Cech, T.R.; Zung, A.J.; Grabowski, P.J. In vitro splicing of the ribosomal RNA precursor of Tetrahymena: Involvement of a guanosine nucleotide in the excision of the intervening sequence. Cell 1981, 27, 487-496. 
2. Guerrier-Takada, C.; Gardiner, K.; Marsh, T.; Pace, N.; Altman, S. The RNA moiety of ribonuclease $\mathrm{P}$ is the catalytic subunit of the enzyme. Cell 1983, 35, 849-857.

3. Gilbert, W. The RNA world. Nature 1986, 319, 618.

4. Woese, C., Ed. The Genetic Code, the Molecular Basis for Genetic Expression; Harper and Row: New York, NY, USA, 1967.

5. Crick, F.H.C. The origin of the genetic code. J. Mol. Biol. 1968, 38, 367-379.

6. Orgel, L.E. Evolution of genetic apparatus. J. Mol. Biol. 1968, 38, 381-393.

7. Orgel, L.E. A simple nucleic acid. Science 2000, 290, 1306-1307.

8. Szostak, J.W.; Ellington, A.D. In vivo Selection of Functional RNA Sequences. In The RNA World; Gesteland, R.K., Atkins, J.F., Eds.; Cold Spring Harbor Laboratory Press: New York, NY, USA, 1993; pp. 511-533.

9. Joyce, G.F.; Orgel, L.E. Prospects for Understanding the Origin of the RNA World. In The RNA World, 2nd ed.; Gesteland, R.F., Cech, T.R., Atkins, J.F., Eds.; Cold Spring Harbor Laboratory Press: New York, NY, USA, 1999; pp. 49-77.

10. Kazakov, S.A.; Altman, S. A trinucleotide can promote metal ion-dependent cleavage of RNA. Proc. Natl. Acad. Sci. USA 1992, 89, 7939-7943.

11. Turk, R.M.; Chumachenko, N.V.; Yarus, M. Multiple translational products from a five-nucleotide Ribozyme. Proc. Natl. Acad. Sci. USA 2010, 107, 4585-4589.

12. Ferris, J.P. Montmorillonite catalysis of 30-50 mer oligonucleotides: Laboratory demonstration of potential steps in the origin of the RNA world. Orig. Life Evol. Biosph. 2002, 32, 311-332.

13. Huang, W.; Ferris, J.P. One-step, regioselective synthesis of up to 50-mers of RNA oligomers by montmorillonite catalysis. J. Am. Chem. Soc. 2006, 128, 8914-8919.

14. Joshi, P.C.; Pitsch, S.; Ferris, J.P. Chiral selectivity in the montmorillonite-catalyzed prebiotic synthesis of RNA. Chem. Commun. 2000, 24, 2497-2498.

15. Joshi, P.C.; Pitsch, S.; Ferris, J.P. Selectivity of montmorillonite catalyzed prebiotic reactions of D,L-nucleotides. Orig. Life Evol. Biosph. 2007, 37, 3-26.

16. Joshi, P.C.; Aldersley, M.F.; Ferris, J.P. Progress in demonstrating total homochiral selection in montmorillonite-catalyzed RNA synthesis. Biochem. Biophys. Res. Commun. 2011, 413, 594-598.

17. Joshi, P.C.; Aldersley, M.F.; Ferris, J.P. Homochiral selectivity in RNA synthesis: Montmorillonite-catalyzed quaternary reactions of D,L-purine with D,L-pyrimidine nucleotides. Orig. Life Evol. Biosph. 2011, 41, 213-236.

18. Joshi, P.C.; Aldersley, M.F.; Ferris, J.P. Progress in Demonstrating Homochiral selection in Prebiotic RNA Synthesis. Adv. Space Res. 2013, 51, 772-779.

19. Joshi, P.C.; Aldersley, M.F.; Delano, J.W.; Ferris, J.P. Mechanism of montmorillonite catalysis in the formation of RNA oligomers. J. Am. Chem. Soc. 2009, 131, 13369-13374.

20. Sleep, N.H. The hadean-archaena environment. Cold Spring Harb. Perspect. Biol. 2010, 2, a002527.

21. Knauth, L.P. Temperature and salinity history of the precambrian ocean: Implications for the course of microbial evolution. Palaegeogr. Palaeoclimatol. Palacoecol. 2005, 2190, 53-69.

22. Knauth, L.P. Salinity history of the Earth's early ocean. Nature 1998, 395, 554-555.

23. Madsen, F.T.; Muller-Vonmoos, M. The swelling behavior of clays. Appl. Clay Sci. 1989, 4, 143-156.

24. Ponnuswamy, N.; Cougnon, F.B.L.; Clough, J.M.; Pantos G.D.; Sanders, J.K.M. Discovery of an organic trefoil knot. Science 2012, 338, 783-785. 
25. Kool, E.T.; Breslow, R. Dichotomous salt effects in the hydrophobic acceleration of benzoin condensation. J. Am. Chem. Soc. 1988, 110, 1596-1597.

26. Morrison, R.T.; Boyd, R.N. Organic Chemistry, 5th ed.; Allyn\&Bacon, Inc.: Boston, MA, USA, 1987; p. 150.

27. Sarfati, J. Origins of life: The chirality problem. J. Creat. 1998, 12, 263-266.

28. Aldersley, M.F.; Joshi, P.C.; Price, J.D.; Ferris, J.P. The role of montmorillonite in its catalysis of RNA synthesis. Appl. Clay Sci. 2011, 54, 1-14.

29. Joshi, P.C.; Aldersley, M.F. Significance of mineral salts in Montmorillonite-catalyzed RNA synthesis. J. Mol. Evol. 2013, 76, 371-379.

30. Dickson, A.G.; Gayet, C. Handbook of Methods for the Analysis of the Various Parameters of the Carbon Dioxide System in Seawater, 2nd ed.; U.S. Department of Energy: Washington, DC, USA, 1994.

(C) 2014 by the authors; licensee MDPI, Basel, Switzerland. This article is an open access article distributed under the terms and conditions of the Creative Commons Attribution license (http://creativecommons.org/licenses/by/3.0/). 